|| ISSN(online): 2589-8698 || ISSN(print): 2589-868X ||

International Journal of Medical and Biomedical Studies

Available Online at www.ijmbs.info

NLM (National Library of Medicine ID: 101738825)

Index Copernicus Value 2019: 79.34

Original Research Article

Volume 5, Issue 8; August: 2021; Page No. 220-222

\title{
OUTCOME OF PRETERM BABIES WITH RESPIRATORY DISTRESS SYNDROME
}

\section{Dr. Shaitan Singh Balai, Dr. Vivek Arora}

MD Pediatrics

Department of Pediatrics, R.N.T. Medical College, Udaipur (Raj.)

Article Info: Received 29 June 2021; Accepted 06 August 2021

DOI: https://doi.org/10.32553/ijmbs.v5i8.2118

Corresponding author: Dr. Shaitan Singh Balai

Conflict of interest: No conflict of interest.

\begin{abstract}
Background: To study outcome of preterm babies with RDS in babies admitted in NICU.

Methods: This study was hospital based prospective study of preterm neonates with respiratory distress syndrome admitted in NICU of MBGH RNT medical college Udaipur, from February 2017 to January 2018.

Results: Among 200 preterm neonates included in the study 31 neonates expired. Mortality was $15.5 \%$. The mortality was $10.17 \%$ among the preterm neonates with RDS and hospitalized within 6 hrs. It was $31.81 \%$ among neonates hospitalized between 6-12 hrs and 62.5\% and 66.66\% among neonates hospitalized between 12-24 hrs and after 24 hrs of birth respectively.

Conclusion: Mortality rate is inversely related to birth weight and gestational age and directly related to age at admission and severity of respiratory distress (Silverman-Anderson score).

Keywords: Preterm, Neonates, Birth weight.
\end{abstract}

\section{Introduction}

Respiratory distress syndrome (RDS), also called neonatal respiratory distress syndrome, ${ }^{1}$ or increasingly surfactant deficiency disorder (SDD), ${ }^{2}$ and previously called hyaline membrane disease (HMD), is a syndrome in premature infants caused by developmental insufficiency of pulmonary surfactant production and structural immaturity in the lungs. It can also be a consequence of neonatal infection. ${ }^{3,4}$ It can also result from a genetic problem with the production of surfactant associated proteins. RDS affects about $1 \%$ of newborn infants and is the leading cause of death in preterminfants. ${ }^{5}$ There has been a tremendous advance in the management of respiratory distress syndrome such as ventilator therapy with different modes such as CPAP, conventional mechanical ventilation, ultra high frequency jet ventilation, surfactant replacement therapy, all have improved the outcome among the babies with respiratory distress syndrome.

\section{Materials and Methods}

Study design and setting: Single center tertiary hospital based prospective study.

Study period: February 2017 to January 2018

Study palace: NICU, Balchikitsalahya MB Govt. Hospital, RNT Medical College Udaipur. All newborn babies admitted to MB Hospital NICU during a period of 1 year from February 2017 to January 2018 who developed respiratory distress syndrome were studied.

\section{Inclusion Criteria}

- Neonates admitted to NICU with respiratory distress.

\section{Exclusion Criteria}

- Babies more than 37 weeks.

- Major congenital malformation.

- Unwillingness in giving informed consent.

- Patient who left against medical advice (before completion of workup)

\section{Study Procedure}

The cases were diagnosed clinically by the presence of at least 2 of the following criteria, namely RR of $60 / \mathrm{min}$ or more, sub costal indrawing, xiphoid retraction, suprasternal indrawing, flaring of alae nasi, expiratory grunt and cyanosis at room temperature. These infants are examined in detail with particular emphasis on gestational age, sex, weight, cyanosis; they are also assessed by scoring systems using Silverman Anderson scoring system. Respiratory, Cardiovascular and Nervous system are examined in detail. They are kept under constant supervision till discharge or death and treatment is carried out for the specific indication. Retrospective study of the mother's significant antenatal history is taken. The diagnosis of clinical conditions producing respiratory distress is based mainly on careful scrutiny of the history, clinical and radiological findings. Continuous monitoring of oxygen saturation is done using pulse oxymeter.

\section{Observations}

A total of 200 preterm babies with diagnosis of RDS were admitted in NICU of Maharana Bhupal Government 
Hospital of RNT Medical College Udaipur during study period. Most of the neonates $167(83.5 \%)$ were hospitalized within $6 \mathrm{hr}$ of birth. 22(11\%) were admitted between 6-12 $\mathrm{hr}, 8(4 \%)$ were admitted between $12-24 \mathrm{hr}, 2(1 \%)$ were admitted between $24-48 \mathrm{hr}, 1(0.5 \%)$ were admitted between
48-72 hr of life. Out of 200 preterm neonates most of the neonates $108(54 \%)$ were $1-1.5 \mathrm{~kg}$ (VLBW). 32(16\%) were $<1 \mathrm{~kg}(\mathrm{ELBW}), 43(21.5 \%)$ were $1.5-2 \mathrm{~kg} \& 17(8.5 \%)$ were $2-2.5 \mathrm{~kg}$.

Table 1: Outcome of preterm neonates with RDS and age at hospitalization in NICU

\begin{tabular}{|l|l|l|l|}
\hline Neonatal age & Total neonates & Expired & $\%$ of mortality \\
\hline$<6 \mathrm{hr}$ & 167 & 17 & $10.17 \%$ \\
\hline $6-12 \mathrm{hr}$ & 22 & 7 & $31.81 \%$ \\
\hline $12-24 \mathrm{hr}$ & 8 & 5 & $62.5 \%$ \\
\hline$>24 \mathrm{hr}$ & 3 & 2 & $66.66 \%$ \\
\hline
\end{tabular}

Among 200 preterm neonates included in the study 31 neonates expired. Mortality was $15.5 \%$. The mortality was $10.17 \%$ among the preterm neonates with RDS and hospitalized within 6 hrs. It was $31.81 \%$ among neonates hospitalized between 6 $12 \mathrm{hrs}$ and $62.5 \%$ and $66.66 \%$ among neonates hospitalized between $12-24$ hrs and after 24 hrs of birth respectively.

Table 2: Birth Weight and Outcome

\begin{tabular}{|l|l|l|}
\hline Birth weight & Total & No. of death \\
\hline$<1 \mathrm{~kg}$ & 32 & $17(53.12 \%)$ \\
\hline $1-1.5 \mathrm{~kg}$ & 108 & $10(9.26 \%)$ \\
\hline $1.5-2 \mathrm{~kg}$ & 43 & $3(6.97 \%)$ \\
\hline $2-2.5 \mathrm{~kg}$ & 17 & $1(5.88 \%)$ \\
\hline Total & 200 & 31 \\
\hline
\end{tabular}

Among ELBW (<1 kg) $17(53.12 \%)$ expired. 10 (9.26\%) expired in VLBW category. 3 (6.97\%) expired in birth weight group of $1.5-2 \mathrm{~kg}$ and $1(5.88 \%)$ neonates expired in birth weight group 2-2.5 kg.

\section{Discussion}

This study was hospital based prospective study of preterm neonates with respiratory distress syndrome admitted in NICU of MBGH RNT medical college Udaipur, from February 2017 to January 2018. Total 200 preterm neonates with respiratory distress who fulfilled the inclusion criteria were enrolled in the study.

In this study we noted a decreasing trend in mortality with increasing weight of the preterm neonates. Bhutta et $\mathrm{al}^{6}$ also reported similar trend in mortality. In their study the overall mortality was $34 \%$ with highest mortality $68 \%$ among newborn infant $<1 \mathrm{~kg}$ birth weight. Jayachandra et $\mathrm{al}^{7}$ also reported similar trend in mortality. In their study mortality was higher $54.5 \%$ among babies with birth weight 1000 1249 grams.

Silverman Anderson score was done in all preterm neonates. 2(2.74\%) neonates expired in the group of neonates with mild respiratory distress, 15 (13.89\%) neonates expired in the group of neonates with moderate respiratory distress and $14(70 \%)$ expired in the group of neonates with severe respiratory distress. Mortality rate was directly related to severity of respiratory distress (Silverman Anderson score).

\section{Conclusion}

Mortality rate is inversely related to birth weight and gestational age and directly related to age at admission and severity of respiratory distress (Silverman-Anderson score).

\section{References}

1. Northway Jr, WH, Rosan RC, Porter DY. Pulmonary disease following respiratory therapy of hyalinemembrane disease. Bronchopulmonary dysplasia. The New England Journal of Medicine, 1967; 276 (7): 357-68.

2. Santosham, Mathuram, Chan, Grace J, Lee, Anne CC, Baqui, Abdullah H, Tan, Jingwen, Black, Robert E. Risk of Early-Onset Neonatal Infection with Maternal Infection or Colonization: A Global Systematic Review and Meta-Analysis. PLoS Medicine, 2013; 10 (8)

3. Sinha S. Essential neonatal medicine. Chichester, West Sussex: John Wiley \& Sons. ISBN 9780470670408, Access provided by the University of Pittsburgh, 2012.

4. Rodriguez RJ, Martin RJ, Fanaroff, AA. Respiratory distress syndrome and its management. In Fanaroff, Avroy A, Martin, Richard J. Neonatal-perinatal 
medicine: diseases of the fetus and infant. St. Louis: Mosby, 2002; 1001-1011.

5. Waldemar A Carlo and Namasivayam. Respiratory distress syndrome. In: Kliegman R, Stanton B, Geme St J, Schor N, editors. Nelson textbook of pediatrics, Vol.1., $20^{\text {th }}$ ed. New Delhi: Reed Elsevier India Pvt. Ltd., 2015; 850.
6. Bhutta ZA, Yusuf K. Neonatal respiratory distress in Karachi. Pediatr, 1997; 11:37-43.

7. Jayachandra Naidu T, Kireeti AS, Lokesh B, Shankar Reddy Dudala, Study Of the Outcome of Early and Late Rescue Surfactant Administration in Preterm Babies. Asian J Health Sci, 2014; 2(2). 